Revue Française de Civilisation Britannique

BRITANNIQUE

French Journal of British Studies

XXV-2 | 2020

Revisiting the UK's North-South Divide: The Changing Face of the North

\title{
Versions of the North in Contemporary Poetry
}

Versions du Nord dans la poésie contemporaine

\section{Claire Hélie}

\section{OpenEdition}

\section{Journals}

Electronic version

URL: http://journals.openedition.org/rfcb/5342

DOI: $10.4000 /$ rfcb. 5342

ISSN: 2429-4373

Publisher

CRECIB - Centre de recherche et d'études en civilisation britannique

\section{Electronic reference}

Claire Hélie, "Versions of the North in Contemporary Poetry », Revue Française de Civilisation

Britannique [Online], XXV-2 | 2020, Online since 25 May 2020, connection on 27 May 2020. URL : http:// journals.openedition.org/rfcb/5342; DOI : https://doi.org/10.4000/rfcb.5342

This text was automatically generated on 27 May 2020

\section{(c)}

Revue française de civilisation britannique est mis à disposition selon les termes de la licence Creative Commons Attribution - Pas d'Utilisation Commerciale - Pas de Modification 4.0 International. 


\title{
Versions of the North in Contemporary Poetry
}

Versions du Nord dans la poésie contemporaine

\author{
Claire Hélie
}

\section{Introduction}

1 A question that is central to any analysis of the North-South Divide in poetry is that of the location of the divide itself. In 1947, W. H. Auden confessed: "To this day Crewe Junction marks the wildly exciting frontier where the alien South ends and the North, my world, begins." In 1970, Tony Harrison moved the frontier further north (and east) when he wrote: "The rot sets in at Retford and the stations beyond." More recently, for Jacob Polley, there seems to be nothing south of Manchester but water. ${ }^{3}$ Joined together, the three dots described by the poets delineate a curve starting at Manchester, running below the Peak District and probably going back up to Grimsby. Yet the frontier is not a fixed one: it is both mobile, seen from a train, and moving ("my world"). So much so that W. H. Auden and Louis MacNeice, on their trip to Iceland, claimed "The North begins inside." ${ }^{\prime 4}$ Indeed, the North in poetry, as opposed to other forms of cultural production, ${ }^{5}$ is first and foremost an experiential place, based on personal experience and historical observation.

2 This raises another important question, in the phrasing of Danny Dorling: "When was the North-South Divide?"6 or in the words of Helen Jewell, what are "the origins of Northern consciousness"? ${ }^{7}$ The Roman settlement, the Danish invasions, the Harrying of the North, the War of the Roses, the Pilgrimage of Grace, the Industrial Revolution, the Miners' Strike all seem to be valid starting points. Along the North / South Divide run many other historical divisions (Angles / French, Protestant / Christian, working-class / bourgeois to name but a few). In this myth of a Britain divided into two parts, the North is coterminous with periphery and margin whereas the South is a synonym for centre and power. Hence a suspicion that national history and definitions of the North are all written from a Southern perspective, through which the North is reduced to " $a$ 
collage of brass band music, flat cap wearing chaps and looming pitheads". ${ }^{8}$ This is what Katie Wales calls "austrocentrism", that is to say a strong bias in histories towards a southern perspective. Therefore, Northern poetry can often be analysed in the light of postcolonial theories: it "writes back" 10 and proposes alternative histories of England. To give but one technical example which is, however, not typical of its author, Ted Hughes, in his essay "Myths, Metres, Rhythms" (1994), fantasizes the history of English poetry as the failed union between a bride, the alliterative verse found in popular verse, in keeping with autochthonous traditions, and a groom, the metre extolled at the Court, and imported from France.

3 In poetry in particular, the North is indeed a soundscape seeking to have its voices and accents heard. Given the diversity of accents in England, one may wonder what the North actually sounds like. Does it have William Wordsworth's Cumbrian accent, which William Hazlitt deemed impossible to understand? Does it show evidence of Basil Bunting's Northumbrian Burr? Is Geordie more northern than Scouse? Besides, in a country where dialects can still be considered as debased versions of Standard English and not as valid linguistic systems, as Katie Wales has shown in Northern English, accents are at the very heart of conceptions of Englishness. A poet like Tony Harrison will make the reader feel the political weight of accents. In a poem entitled "The Rhubarbarians", he quotes the exact words used by William Horsfall, a mill-owner who wanted to crush a Luddite rebellion in Marsden, as quoted in E.P. Thompson's The Making of the English Working-Class (1963):

Horsfall of Ottiwells, if the bugger could

'd've liked to (exact words recorded) ride

up to my saddle-girths in Luddite blood. ${ }^{11}$

If the readers choose to use the Standard English the mill-owner most probably spoke, then they fail to keep up the abab rhyme that is characteristic of the poem: the readers' side with those who have power but destroy the vehicle that is usually associated with their values. If they want to keep the rhyming going, then they have to pronounce " blood" as /blud/, that is to say, with a Northern sound, which will place them on the side of the victims. The poetical choice is a political one.

5 As a "cultural artefact", raising questions of belonging, to the region and to the nation, the North is an "imagined community", as Benedict Anderson terms it, which has benefited from thorough academic investigation, most notably in the 1990s and early 2000s (see bibliography). The expectation is commonly, and as suggested above, that Northern poetry has to be political. Today though still present, this feature is less prominent and it seems the North has entered a new era, in which it is a place to rethink not only England but humanity as a whole. Focusing on a few recent collections of essays and anthologies (2006-2017), the place and definition of the North in poetry nowadays will be assessed, before two collections dedicated to the North, Steve Ely's Oswald's Book of Hours (2013) and Peter Riley's Due North (2015), are examined.

\section{The poetic North in some collections of poems and essays (2006-2017)}

Anthologies, as the etymology goes, make a bouquet out of a selection of flowers, and therefore show both commonality and diversity. In the study of anthologies, more interesting than individual poems which give diverse interpretations of the North, are 
the paratextual elements - preface, postface, endnotes - in which the anthologists painstakingly try to explain what is commonly "northern" about them. Two fairly recent collections, Versions of the North (2013) and North by North-East (2006), ${ }^{12}$ though focusing on two regions within the North which they claim to be The North, namely Yorkshire and the North-East, emphasize common conceptions.

7 First, that being born or living in the North is not sufficient to earn the label "Northern writer" - "strong connections", a sense of organicity or "a history of involvement in the communities in which they live" are more important than birthplace (only $1 / 4$ of the poets in North by North-East were actually born in the region). Hence "a sense of shared history, landscape and character" and "a feeling of belonging, an understanding of shared loyalties". Second, regional poetry cannot be reduced to clichés, though it inevitably deals with them - "dialect verse recited by men in flat caps with whippets at their feet" and "the Geordie Nation" whose identity is "based on a shared heavy-industrial past and an uncertain economic future", are neither exclusive of nor excluded from Northern poetry. The other side of a sense of "remoteness from the centre and seats of power" and "historic distance from the metropolitan centres of authority", namely Westminster government, London media and Oxbridge, is "an awareness of otherness and dissent" and a "participation in the same broken political narrative". Third, northern poets can boast of a few famous poetic forebears: Ted Hughes, Philip Larkin and Donald Davie for Yorkshire and Basil Bunting for the North East where the poet has reached a cult status. Most importantly, they argue that the poems are "from the North East, of the North East, for the North East, but not necessarily 'about' the North East", that they are "versions" of a place, that is to say dependent on a point of view.

8 Yet, an important distinction can be made between the two collections. Versions of the North insists on the fact that boundaries are political constructs - they are arbitrary and that "Yorkshire is a discrete entity, coexisting with, influencing and being influenced by the mainstream". Consequently, it seems that the aim is to put these poems on a par with mainstream English poetry, that is to say with poetry published by the main publishing houses like Faber and Penguin Modern, to see Yorkshire as a part of England. On the contrary, North by North-East insists on a divide that is both geographical and political: most poets are from the political left and together, they write a "poetry of the 'imaginary republic' of the North East, confidently facing South without deferring to London." The poems are either "experimental" or "traditional" but most of them are written in "non-Mandarin English". Consequently, it seems that the aim here is to say that the North East is apart from the rest of England. No matter what the agenda is though, anthologies of northern poems fulfil a double role: they preserve the works of local poets who might not be read otherwise alongside more established poets and they create a canon of Northern poems, in other words, they participate in creating a Northern poetry.

Both collections claim that Northern poetry is made possible by a change in publishing patterns and give a whole list of local publications, past anthologies, presses, magazines and cultural structures to prove their assertion that publishing poetry in the North has become a vibrant activity. The North-South Divide in poetry was often played out along the lines of small presses and provincial publishers (like The North and Bloodaxe) circulating experimental poetry versus The Poetry Society and London or Southern publishers (Anvill, Faber, OUP) circulating mainstream poetry. Therefore, whereas in the 1960s, many poets deplored the fact that they could not get published by Londonbased publishing houses because they were deemed northern, a quick look at the 
presses listed on the Poetry Library website ${ }^{13}$ shows that today things have taken a turn for a better representation of poetry in every British region. Indeed, some 65 publishing houses are located in the South and the Midlands, 25 in the North and 25 elsewhere. Considering that the North is actually made up of three regions (Yorkshire and the Humber, the North East and the North West) out of nine, a sense of balance emerges.

The two collections stress how important this change has been. For Versions of the North, it is "the breakup of the Oxford-Cambridge-London axis which dominated poetry publishing in the UK for so long, and the subsequent emergence of magazines and presses in the North, many of which based in Yorkshire", which explain the important amount of poetry produced in the region. The statement is confirmed in North by North-East, in the sense that "poets in the North-East no longer need to look to London publishers for their work to be validated." The change started in the 1960s in a context of urban regeneration in which the Arts played an important role. Hence the fact that the label "Northern poetry" usually refers to different sets of poets working together, more or less tightly, within a particular city. For instance, Jon Silkin's Stand was founded in London in the 1950s, but when the poet gained a Gregory fellowship from the University of Leeds in 1960, he based his magazine in the North and ran it without any subsidy until 1965. Numerous poets who were on a Leeds university fellowship, like Tony Harrison, contributed to the magazine, at a time when fiery discussion over the political nature of poetry fuelled the British Poetry Revival. The then North-East Association for the Arts invited Silkin to relocate into Newcastle, another such poetic hubbub: Tom and Connie Pickard's Mordern Tower, Bloodaxe, which was founded so as to publish and publicize Basil Bunting's Briggflatts (1965), a long epic poem on the North that all London-based presses had turned down according to its author, as well as a pro-active policy of funding the Arts, for instance through Northern Arts fellowships, which Harrison and Bunting also benefited from, were gaining the city international recognition on the poetic scene. After the 1987 elections, which saw the return of the conservatives to power due to the rise of unemployment in the aftermath of the 1984-1985 Miners' Strike and the wave of deindustrialisation that submerged the North, the Regional Arts association invested in community arts activity in areas of high unemployment, which explains the poetry revival of the 1990s. In 1999, the editorial offices of Stand, by then a reputed magazine, moved back to Leeds, that is to say, stayed in the North.

11 A look at a few collections of essays on contemporary poetry shows the story is not that simple though. The Cambridge Introduction to British Poetry, 1945-2010, edited by Eric Falci in 2015, has one chapter on "The North" (pp. 126-154) whose title is misleading for the purpose of this article since it deals with Northern Irish poetry since 1968. Elsewhere in the book, apart from Basil Bunting whose northerness is alluded to, poets who are traditionally associated with the North are analysed along different lines: Ted Hughes for his modern primitivism; Tony Harrison because of the class struggle he testifies to; and Simon Armitage as a performer. The Cambridge Companion to British Poetry, 1945-2010, edited by Edward Larissy in 2016, does not allegedly have a chapter on Northern poets but one on "Poetry and Class" (pp.116-129) by Sandie Byrne, who proposes a survey "of some poetry in English on the subject of social inequality" ${ }^{14}$. Though claiming that her study is not attached to one particular region, Byrne spends some time on Leeds and lists Blake Morrison, Tony Harrison, Ken Smith and Tom Pickard, all born and bred in the North, as example of poets who tackle the issue of class in their poetry. When she 
moves on to her analysis of Sean O'Brien's poetry, she writes "also intransigently northern, though born in London" (p.122), most probably a slip of the pen, given her initial caveat. Yet, while explaining the social nature of Cousin Coat, she uses the phrases " northerness conceived as...", in "O'Brien's North", and finally "northern working-class popular culture" (p. 123), a phrase that definitely associates the North and the workingclass. She then moves further North with a series of Scottish poets, namely Don Paterson, Douglas Dunn, and Tom Leonard. Finally, The Oxford Handbook of Contemporary British and Irish Poetry, edited by Peter Robinson in 2013, has one chapter by David Wheatley entitled "'Dafter than we care to own': Some Poets of the North of England" (pp. 407-423). Wheatley's own Contemporary British Poetry, published in London in 2015, had no chapter and no reference to a northern trend in poetry. Yet his contribution to Robinson's collection of essays hardly makes up for it since it is actually not so much about the North as it is about Hull and its vibrant poetic scene since Larkin started working there as a librarian. Two conclusions that can be drawn are that the North, when mentioned, is still considered in social terms as opposed to aesthetic ones, and that it is difficult, because of the diversity of the region, to go beyond the local towards the regional level when analysing it. It is hard though to draw definite conclusions as to why the North is not theorised or represented at all: is it because the purpose of the book does not encompass the issue of the North? Or because northerness is deemed a 1980s issue? Or simply because it does not deserve to be tackled at all? There is no definite reason for this lack of comprehensive analysis.

\section{Steve Ely's Oswald's Book of Hours (2013) ${ }^{15}$}

Steve Ely was born and bred in Yorkshire. On his website ${ }^{16}$, he describes himself as a " poacher, preacher: poet" and indeed, hunting, Catholicism and language are his main concerns, together with local history and literature. He is a Ted Hughes scholar and has inherited his elder's poetics of violence as a natural process that penetrates all layers of existence. In his 2013 biography, he demonstrated that the time the Poet Laureate spent in Mexborough, a once heavily industrial town, was at least as formative as the years he spent in the natural landscapes of the Calder Valley, which most critics point out as his primary poetical influence. This debatable assertion about Ted Hughes tells us one important thing about Ely himself: he is a staunch supporter of the workingclass and of mining communities. For instance, Arthur Scargill, the NUM leader of the 1984-85 UK Miners' strike, who had already been turned into a poetic icon by Tony Harrison in his controversial v. (1987), appears in the section "Memorials of the Saints", and in a sonnet no less. In other words, Steve Ely writes a "Ted Hughes meet Tony Harrison" kind of poetry and the least to be said is that the result is not for the faint at heart.

13 The central figure is King Oswald, who reigned over Northumbria from 635 to $642 \mathrm{AD}$ and spread Christianity across England against pagan and foreign forces. Ely describes him as:

a key and neglected figure in English history and a touchstone for many of the issues and themes that pre-occupy me - the role of the North in the larger polity of England, the English propensity for violence, the Catholic roots of England, hunting with dogs, natural history, landscape, class, race, resistance and rebellion, the relationship of England the gaeltacht [sic] - and others ${ }^{17}$. 

specific to Ely's own poetics (hunting for instance). Oswald's story is one of defeat in battle against the Mercians, of usurpation of posterity, since George became patron saint of England, and of neglect, as he is only mentioned passim in history books. His fighting spirit and destiny are to be found in other northern figures in the collection: Richard Rolle, a $14^{\text {th }}$ century hermit, Robert Aske, a Catholic rebel who was executed after participating in the Pilgrimage of Grace in 1536, John Nevison, a $17^{\text {th }}$ century highwayman who ended up hanged, or Stewart MacLaughlin, a paratrooper who was killed aged 27 during the Falklands War. He also appropriates figures whose Northerness is either disputed, like Robin Hood, or plain non-existent, like Wat Tyler, the Canterbury leader of the Peasants' Revolt in 1381. Such a pantheon indicates that for Ely, class allegiance is more important than geographical location and therefore that Northern stands for rebels who pay the high price when repression strikes. This is actually a recurring feature in Northern culture: the phrase "Rebellious North" is found in The Tears of Cambria, an $18^{\text {th }}$ century poem, in a 1961 letter from the Selected Letters of William Empson (2006), and it is the title of an animation funded by the Arts Council in 2015. The connection is actually so strong that it conflates other identities, as in Lemn Sissay's Rebel Without Applause (1992), in which the poet presents himself as a Black rebel of the North.

In Ely's "exploration of radical, pre-industrial and pre-reformation traditions"18, eulogies and laments have nothing nostalgic or melancholy about them. Such feelings are kept at bay by the many references to hunting, deemed a regulated though cruel practice. For instance, the very first poem is a calendar of hunting trips filled with gory details ("the boar's blood smeared / on beardless cheeks", p.11; "man and dogge / had of his flesh their share and even the corbyn / had their bone", p.12; "we left the meat for scavenging corbyn, ligged in reddening snow", p.13). This violence (but whose violence? The violence of hounds? of individual men? of history? of political and social structures? of the North?), this violence reverberates in the other poems and forces us to beg the question: does the poet endorse the violence his personae stand for? Knowing Steve Ely's self-proclaimed affiliation with revolutionary socialism, there is little doubt that Wat Tyler's words are also his:

15. Sainted King Oswald, heed well my lesson. When your moment arrives, seize it: lead the fyrd of your people to palace of Westminster and hesitate not to treat it with fire; 16. And no doubt that your people, should you ever oppress them or lead them astray, will turn upon your Northumbrian tower, with springhole and trebuchet, block, scaffold and hatchet. (pp. 20-21)

Indeed, I would argue that the violence described in his book, the contempt he shows for the weak in spirit and body, the deliberate violation of delicate sensibility, sentiment and softness, his rejection of charity works, compassion and pity, all have a unique target: the middle class, who live in a luxury the workers have always paid for with their own lives, who exert control over the arts, who have usurped and are despoiling England. The question of who the land belongs to is actually a recurring one (p.15, pp. 45-46). The rhetoric here is one of sheer evidence: it belongs to the people.

Violence and destruction are also a linguistic matter. Standard English, Northern dialect, Old English, Latin, foreign languages are mixed, which could make us think either that the North is a melting pot, or that historicising and locating the language is a way to create a linear history of the region, but that would be too simple a story. In

Revue Française de Civilisation Britannique, XXV-2 | 2020 
fact, there is no consistency in the spelling at all. For instance, in the first poem, "sin" is spelt "synne" (p.11), "sinne" (p.12), "sinn" (p.14). Some forms are even plain wrong. Peter Riley notes that the collection is fraught with mock archaic language that constantly arrests the eye and the ear with impossible forms such as the -eth suffix which is normally used for a verb in the $3^{\text {rd }}$ person singular but which is used here for an infinitive or a past participle. ${ }^{19}$ Jacques Rancière, who can be deemed a radical thinker working in the same vein as Terry Eagleton or Raymond Williams, in The Politics of Literature, argues that "literature does politics simply by being literature" 20 and it does so by introducing misunderstandings that reconfigure the relationships between words and things. "Metathesis" (p.83) ${ }^{21}$, a current linguistic process which alters the shape of words and which is mentioned in the last poem of the collection is not a smooth process but an act of linguistic destruction. Revolution through fighting has come to a dead end (all the personae in the collection speak from the dead and no contemporary hero or even villain is mentioned), so only language and literature can be revolutionary today. Yet Steve Ely's distorting of poetic forms and language is as political an act as can be. This is his own personal way of reviving the spirit of the rebellious North.

\section{Peter Riley's Due North (2015) ${ }^{22}$}

Peter Riley was born in Stockport, near Manchester, in 1940, in a rather modest family, and "found [his] way into a university", Cambridge University no less. He "never settled" 23 but spent most of his adult life in the South and abroad. He is associated with different movements of experimental poetry (the Cambridge poets and the American $\mathrm{L}=\mathrm{A}=\mathrm{N}=\mathrm{G}=\mathrm{U}=\mathrm{A}=\mathrm{G}=\mathrm{E}$ poets) which, in the wake of Ezra Pound and other Modernists, promoted a form of cosmopolitan writing. And yet, most of his collections focus on one specific British place: Alstonefield (2003) on Staffordshire, The Llyn Writings (2007) on Wales, The Derbyshire Poems (2010) on Derbyshire. Due North (2015) is his second fullfledged collection to deal with the matter of the North. The first one, Distant Points: Excavations Part One Books One and Two, published in 1995, contained a series of meditative prose poems on the prehistorical burial mounds that had been found in the Yorkshire Wolds in the $19^{\text {th }}$ century and described in J. R. Mortimer's Forty Years' Researches in British and Saxon Burial Mounds in East Yorkshire (1905). Pennine Tales, a pamphlet published in 2016, is a series of loco-descriptive poems that home in on the Calder Valley, an area celebrated by many poets from and around the region such as former Poet Laureate Ted Hughes and current Professor of Poetry at Oxford Simon Armitage.

Even though Due North was begun the day before Riley moved back from Cambridge to Yorkshire after almost a whole life time away, the collection contains few elements of his personal coming back story to the North. Instead, there are countless patterns and modes of migration to the North, which is not construed, at the onset, as a place of hope for a better life or of return to a golden age, but as a place where there may just be a slim hope of survival. Indeed, the reasons for taking to the road are many, be it traditional migration, like the pastoral nomadic hunter gatherers of the first section, $19^{\text {th }}$ and $20^{\text {th }}$ century larger migratory fluxes, like the ones induced by the Industrial Revolution, wars (as in section four) and climate change, or even forms of walking against power, such as the ascent of Kinder Scout in section 11. Therefore, each of the 12 sections takes us on a journey "from far" (the very first words of the collection) to " 
somewhere under the terminus" (its very last words) (p.96). Consequently, Due North is both cosmopolitan and northern. For instance, section five recounts the experience of an "artistic vertigo from Stockport to Anarchy and Surrealism" (p.38) and

back

from Surrealism to the Stockport of death, the great brick viaduct still striding across the town in 27

arches like letters of the alphabet spelling $\mathrm{p}$ o é $\mathrm{s}$ i $\mathrm{e}^{24}$

In other words, the physical movement forward and / or back to the North is also a poetic movement that originates and terminates in the poetic North.

The journeys are filled with the unknown and the hopes crashing on the way seem as important as the reality of arrival with its disillusions. There is a drive forward though, which recalls Gilles Deleuze and Felix Guattari's work on the "lines of flight", "rhizomes" and "war machines" in A Thousand Plateaus (1987), or more precisely their analysis in the realm of poetics by Pierre Joris in his A Nomad Poetics (2013). Indeed, Joris argues that “ the days of everything static - form, content, state - are over. The past century has shown that anything not involved in continuous transformation hardens and dies" 25 . The journeys to the North are indeed not direct trajectories to the North but continual experiments with place and poetry. How can a long poem, entitled "Due North" which exhibits its northerness through its cover picture (a photograph of Heights Road, Hebden Bridge, by Richard Gascoigne) and deictic contents (place names, dialecticisms, historical realia...) be reconciled with deterritorialisation and nomad poetics?

Joris further describes nomadic poetics as "a war machine, always on the move, always changing, morphing, moving through languages, cultures, terrains, times without stopping. Refuelling halts are called poases, they last a night or a day, the time of a poem, \& then move on". ${ }^{26}$ The reader is made to feel the defamiliarisation the nomad or migrant is faced with. For instance, the use of northernisms stands in sharp contrast with languages from all over Europe (Latin, German, Spanish, French, Italian, Polish...). As for the line length, the layout, the multiple typefaces (capital letters, italics, inter letter space, bold type...), they destabilize the reading so much that the eye feels like it is always on the move in some sort of chaotic way. Joris's poasis (pl. poases) is a neologism that refers to "a poem-oasis, i.e. a stop in the moving along the nomad lineof-flight". ${ }^{27}$ The idea is that the North provides such a refuelling halt, that it is a poasis that makes "a movement-in-rest" possible. Therefore, even located in the North, the poem is still on the move because it points to elsewheres.

Section 12 is of particular interest because it deals with Angel Meadow, a once affluent area turned into slums during the Industrial Revolution and rehabilitated into a park in the early 2000s. The first part opens with the line "The future sucks in the victims of a demographic disaster" and goes on to name other victims: "destitute Irish fleeing the famine, those who survived the crossing, / Ashkenazi Jews fleeing central European pogroms". Angel Meadow offered no bright future but "mass graves with tombstones" (p.87) for those "who escaped rural destitution to die of typhoid or cholera in the darkness" (p.88). Even though the text hints at different reasons why Meadow Angel was turned into a nightmare in the 19th century ("a constant refusal to act, Tory spite, corporate disdain, coterie verse", "cholera, people dying into / the success and obsolescence of the entire structure "), in the endnote, the poet refuses to put the blame on the local industry: "It is not then a matter of the building of the textile industry of the Industrial Revolution but rather of the inability at a somewhat larger stage to cope with trade fluctuations and demographical disasters 
elsewhere" (p. 101). The rhetoric of approximation at work here ("somewhat", "elsewhere ") allows to name no culprit for stories of painful uprooting, to leave interpretations open and to show that the North is but a halt in an extended and constantly moving network. In other words, the local structures and organisations and events that cause not to say thrive on - migration are not important. Migration escapes any kind of attachment to a grid.

The view is not pessimistic though because something can be done. In 2000, Peter Riley detailed what could be called his moral compass:

The east-west tensions concern living and dying, beginning, continuing and ending, settlement and economy, whereas the north-south tensions concern something else, like possibility and impossibility, comfort and hurt, politics, science, hope and despair... and these cardinal tensions are still there, translate them as you will. ${ }^{28}$

The dialectics of hope and despair is indeed at the heart of Due North, because what matters, more than the structures themselves, is the people who run these structures, or are run by these structures, or run by these structures without even casting a compassionate glance. Hence the search for a "we" throughout the collection, a "we" that would not entail a universal lyricism of humankind since the people and peoples mentioned are always acted on by a specific history and geography. Peter Riley gives a very generous reading of the whole poem for free on Soundcloud ${ }^{29}$ and all the "uses" are pronounced the northern way as [uz] and not $[\Lambda s]$. This [uz] is one of inclusion, of welcoming, of the human warmth associated with Northerners, it is both "loving and funny" as Tony Harrison claims in his "Them \& [uz]". Due North is a quest for some kind of choral "we" that would help us connect emotionally with what is happening around us, that would teach us empathy. That point is illustrated in:

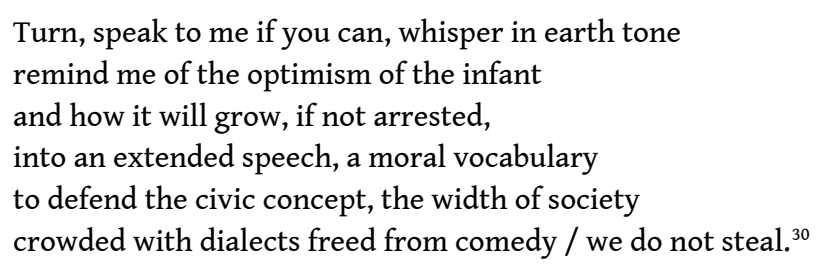

Here, an " $I$ " speaks to an unnamed "you" begging for a language of the earth, a language that is unspoken as the etymology of the word "infant" suggests, a language that will go beyond any linguistic territory. "Turn", the very first word of the stanza, comes from the Latin "verso", which also gave the word "verse", meaning that in poetry and in empathy lies our hope for a better future.

\section{Conclusion}

This article has tried to show that the North was still an imagined community, or, more precisely, that its constant mapping in poetry imagined communities, be they of the past, of the present, or of the future. From the local to the national to the universal, the scale changes but the sentiment does not - up North is the route to alternative, countercultural, oppositional representations of the nation and of humanity. Yet, as opposed to some Scottish poets, Northern poets do not write for a political devolution, but through an aesthetical independence. In other words, they are looking for a form of writing that would tip the balance and renew the dialogue with the other half of England. 


\section{BIBLIOGRAPHY}

Anderson, Benedict, Imagined Communities (London, Verso, [1983] 1991).

Ashcroft, Bill, Griffiths, Gareth, and Tiffin, Helen, The Empire Writes Back: Theory and Practice in Post-Colonial Literatures (London, Routledge, 1989).

Auden, W.H, "I Like It Cold", House and Garden, December 1947.

--- and MacNeice, Louis, Letters from Iceland (London, Faber, 1937).

Baker, Alan R.H. and Billinge, Mark (eds), Geographies of England: The North-South Divide, Material and Imagined (Cambridge, Cambridge University Press, 2004).

Byrne Sandie, "Poetry and Class", in Edward Larissy (ed.), The Cambridge Companion to British Poetry, 1945-2010 (Cambridge, Cambridge University Press, 2016), pp. 116-129.

Croft, Andy and Fuller, Cynthia (eds), North by North-East: The Region's Contemporary Poetry, Northumberland, Iron Press, 2006).

Deleuze, Gilles and Guattari, Felix, A Thousand Plateaus: Capitalism and Schizophrenia, transl. Brian Massumi (Minneapolis, University of Minnesota, 2005).

Ely, Steve, Oswald's Book of Hours (Middlesbrough, Smokestack Books, 2013).

Falci, Eric (ed.), The Cambridge Introduction to British Poetry, 1945-2010 (Cambridge, Cambridge University Press, 2015).

Harrison, Tony, Collected Poems (London, Penguin, 2016).

Hughes, Ted, Winter Pollen: Occasional Prose (London, Faber, 1994).

Jewell, Helen, The North-South Divide: The Origins of Northern Consciousness in England (Manchester, Manchester University Press,1994).

Joris, Pierre, A Nomad Poetics: Essays (Connecticut, Wesleyan University Press, 2003).

Larissy, Edward (ed.), The Cambridge Companion to British Poetry, 1945-2010 (Cambridge, Cambridge University Press, 2016).

Macmillan, Ian, « A Poetic Approach to Life in the North », Yorkshire Post, 19 April 2013, URL: http://www.yorkshirepost.co.uk/lifestyle/books/a-poetic-approach-to-life-in-thenorth-1-5592467.

Parks, Ian (ed.), Versions of the North: Contemporary Yorkshire Poetry (Nottingham, Five Leaves Publications, 2013).

Polley, Jacob, The Brink (London, Picador, 2003).

Rancière, Jacques, The Politics of Literature, transl. Julie Rose (Cambridge, Polity Press, 2011).

Riley, Peter, Due North (Bristol, Shearsman Books, 2015).

Robinson, Peter (ed.), The Oxford Handbook of Contemporary British and Irish Poetry (Oxford, Oxford University Press, 2013).

Russell, Dave, Looking North: Northern England and the National Imagination (Manchester, Manchester University Press, 2004). 
Thompson, Edward Palmer, The Making of the English Working Class (Harmondsworth, Penguin, [1963] 1991).

Wales, Katie, Northern English: A Cultural and Social History (Cambridge, Cambridge University Press, 2006).

Wheatley, David, Contemporary British Poetry (London, Palgrave, 2015).

\section{NOTES}

1. W.H. Auden, "I Like It Cold", House and Garden, December 1947, p. 110.

2. Tony Harrison, "The Death of the PWD Man", Collected Poems (London, Penguin, 2016), p. 48.

3. Jacob Polley, “The North-South Divide”, The Brink (London, Picador, 2003).

4. Louis MacNeice, “Epilogue for W.H. Auden”, Letters from Iceland (London, Faber, 1937), p. 251.

5. Dave Russell in Looking North: Northern England and the National Imagination writes: "Most people outside the North and many within it have come to know the region not through personal experience but via the versions they encounter in the field of culture." Dave RUSSELL, Looking North: Northern England and the National Imagination (Manchester, Manchester University Press, 2004), p. 4.

6. Danny Dorling, "Distressed Times and Areas: Poverty, Polarisation and Politics in England, 1918-1971", in Alan R.H. Baker and Mark Billinge eds., Geographies of England: The North-South Divide, Material and Imagined (Cambridge, Cambridge University Press, 2004), p. 46.

7. Helen Jewell, The North-South Divide: The Origins of Northern Consciousness in England (Manchester, Manchester University Press), 1994.

8. Ian Macmillan, "A Poetic Approach to Life in the North", Yorkshire Post, 19 April 2013. URL : http://www.yorkshirepost.co.uk/lifestyle/books/a-poetic-approach-to-life-in-thenorth-1-5592467. Last accessed 15.05.2017.

9. Katie Wales, Northern English: A Cultural and Social History (Cambridge, Cambridge University Press, 2006), p. 2.

10. Bill Ashcroft, Gareth Griffiths and Helen Tiffin, The Empire Writes Back: Theory and Practice in Post-Colonial Literatures (London, Routledge, 1989).

11. Tony Harrison, “The Rhubarbarians”, op.cit., pp. 123-124.

12. Ian Parks (ed.), Versions of the North: Contemporary Yorkshire Poetry (Nottingham, Five Leaves Publications, 2013), pp. IX-XIII. Andy Croft and Cynthia Fuller (eds), North by North-East: The Region's Contemporary Poetry (Northumberland, Iron Press, 2006), pp. 3-9.

13. http://www.poetrylibrary.org.uk/publishers/poetrybook/

14. Sandie Byrne, "Poetry and Class", in Edward Larissy (ed.), The Cambridge Companion to British Poetry, 1945-2010 (Cambridge, Cambridge University Press, 2016), p. 116-129.

15. Steve Ely, Oswald's Book of Hours (Middlesbrough, Smokestack Books, 2013).

16. https://steveely.wordpress.com/. Last accessed 15.05.2017. The blog is no longer edited.

17. http://www.forwardartsfoundation.org/wp-content/uploads/Steve-Ely-talking-points.pdf. Last accessed 15.05.2017.

18. Steve Ely, op.cit. backcover.

19. http://fortnightlyreview.co.uk/2015/01/northern-poets/ 
20. Jacques Rancière, The Politics of Literature, transl. Julie Rose, (Cambridge, Polity Press, 2011), p. 3.

21. Steve Ely, op.cit.

22. Peter Riley, Due North (Bristol, Shearsman Books, 2015).

23. http://www.aprileye.co.uk/biography.html

24. Peter Riley, op. cit., p. 39.

25. Pierre Joris, A Nomad Poetics: Essays (Connecticut, Wesleyan University Press, 2003), p. 6.

26. Ibid., p. 26

27. Ibid., p. 47.

28. http://jacketmagazine.com/11/riley-iv-by-tuma.html

29. https://soundcloud.com/peterriley-duenorth

30. Peter Riley, op.cit., p. 39.

\section{ABSTRACTS}

Based on a range of anthologies and collections mostly published since 2013, this paper analyses different faces of the North in poetry, from a heavily industrial place filled with the violence of history to a land of opportunity for a brighter future. In doing so, it tries to elucidate what the North means in poetry and what poetry does to representations of the North. A paper on poetry in a journal devoted to British social studies, even though tackling the theme of the issue, namely the North-South Divide today, might come as a surprise to most readers. Hopefully, the present article will prove that verse is not adverse to a reflection on the state of Britain and that the divide between the two fields of study can be bridged and help further research.

A partir d'un ensemble d'anthologies et de recueils, pour la plupart publiés depuis 2013, cet article se propose d'analyser les différentes facettes du Nord en poésie, d'un espace industrialisé où la violence règne, à une terre des possibles tournée vers des lendemains qui chantent. Ce faisant, il essaiera d'élucider ce que le Nord signifie en poésie et ce que la poésie fait au Nord. Un article sur la poésie dans une revue consacrée à la civilisation britannique, quand bien même il aborde le sujet du numéro, peut surprendre plus d'un lecteur. Nous espérons cependant que cet article montrera que la forme poétique n'exclut pas une réflexion profonde sur l'état de la nation britannique et que l'écart entre les deux champs disciplinaires peut être résorbé et participer à faire avancer la recherche.

\section{INDEX}

Mots-clés: Nord de l'Angleterre, poésie, anthologies, Steve Ely, Peter Riley

Keywords: Northern England, poetry, anthologies, Steve Ely, Peter Riley 
AUTHOR

CLAIRE HÉLIE

CECILLE (EA 4074), Université de Lille 